\title{
A biblical evaluation of Healing begins with sanctification of the heart by M.K. Strydom (2013)
}

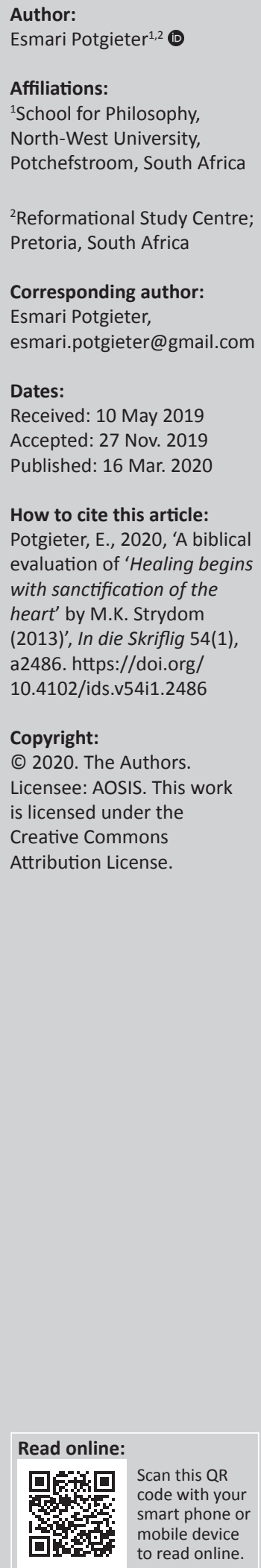

Dr Michelle Strydom is a South African trained medical doctor whose conferences and writings have gained her and her ministry, known as 'Eagles' Wings', a large following in South Africa and beyond. Her aim is to open up for her followers 'the Bible from a medical perspective' and 'medicine from a Biblical perspective'. Her views are comprehensively laid out in a book of 751 pages, titled Healing begins with the sanctification of the heart. In this article, the theological premises of Healing begins with the sanctification of the heart are evaluated from a Reformed biblical perspective. Three theological 'leaps' in Strydom's interpretation of the Bible are discussed and three examples are given which illustrate her a-contextual reading of the Bible. The conclusion is that, although Strydom's book contains some valuable insights, her theological framework is largely unbiblical and contrary to the gospel. The purpose of this article is to caution Christian readers against false guarantees of healing such as these offered by Strydom and Eagles' Wings Ministries.

Keywords: M.K. Strydom; Eagles' Wings; healing; disease; prosperity gospel; prosperity gospel in South Africa; Christian view of health; Christian view of sickness.

\section{Introduction}

Dr Michelle Strydom is a South African trained medical doctor who calls her ministry, known as Eagles' Wings, a 'medical ministry' (Eagles' Wings n.d:1 of 2). Her aim is broader than simply medical, as she wants to open for her followers 'the Bible from a medical perspective' and 'medicine from a Biblical perspective' (Strydom 2019). Dr Strydom's book, Healing begins with sanctification of the heart, has seen four editions and is now freely available on the Internet (Strydom 2013). Moreover, this book of 751 pages forms the basis of all her teachings given through conferences and other resources by Eagles' Wings (Eagles' Wings n.d.:2 of 2).

This article is an attempt to evaluate the theological premises of Healing begins with the sanctification of the heart from a biblical perspective. ${ }^{1}$ I will indicate that, while the book contains some valuable insights, its theological framework is to a large extent unbiblical. In the introduction of her book, Dr Strydom (2013:1) promises:

I'm going to take you into the foundation of all diseases as I give you insight into the spiritual, psychological and physical mechanisms that produce disease. I am going to show you how your thoughts and the things that you meditate on long term cause biological manifestation in the form of disease in your body.

Timely insights are found in the book. I highlight three of them:

- Bodily disease can be the result of a sinful lifestyle or faulty thought patterns. Believers who become ill should investigate this possibility with serious reflection and prayer. If they discover that their illness has been caused through sinful patterns in their life, they should repent (with sincerity, and not only in order to be healed).

- Believers, especially Western believers, should guard against thinking that all problems and their solutions are simply of a material or physical nature. The bodily, mental, spiritual and other functions of a human being are intertwined (cf. also Coetzer 2013:99-123).

- God still gives healing today in answer to the prayers of his children.

With appreciation for Dr Strydom's emphasis on biblical truths such as the above, Inevertheless, do want to highlight significant problems in her theological framework. This framework is laid out in the first three parts of her book, especially in Part 1.3, which contains subtitles such as the following:

1.Standing in the Reformed tradition, I am guided in my interpretation of the Bible by the Three Forms of Unity and by the grammaticohistorical method of interpretation. 
- 'The condition for healing is repentance'

- 'God's Perfect Will is not healing; his Perfect Will is that you don't get sick'

- 'Protection from physical trauma and disease comes from obedience'

- 'It is God's Will to heal you today!'

With statements such as these, Strydom shows her attachment to the prosperity theology. Her theology shares many of the problems that are commonly found in the prosperity theology (cf. Magezi \& Manzanga 2016; Maura et al. 2015). However, in this evaluation, I will focus on three specific problems in Strydom's handling of the Bible. I call these problems 'leaps', because they reflect a tendency to draw straightforward connections between realities that are in fact connected in much more complex ways in Scripture. The three leaps that will be discussed, are the following:

- the leap from the Fall to individual sin;

- the leap from Israel to the New Testament Church; and

- the leap from spiritual to temporary blessings.

After discussing these three leaps, I will illustrate in three examples Strydom's a-contextual handling of Scripture. In closing, I will highlight three concerns regarding her scientific method.

\section{A leap from the Fall to individual sin}

The Bible and everyday experience teach us that God commands his sun to shine and his rain to fall on all peoplebelievers as well as unbelievers (Mt 5:45). Yet the opposite is also true. When a drought or a cyclone hits an area, then everyone - believers and unbelievers - feels its effects. Remember the Black Death pandemic that hit Europe in the 14 th century and took as many as 200 million lives. Think of more recent disasters: Ebola breaking out in West Africa, or the cyclone Idai hitting Mozambique. In all these cases there were true Christians as well as non-Christians among the victims.

Why do Christians also get sick? Strydom (2013) gives the following explanation:

There are some people who struggle to understand why Christians get sick. The reason that the church has the same biological and psychological diseases as the world is because we are serving the same sin with the same consequences. (p. 32)

In my view, this is a simplistic explanation which overlooks the close-knit bond that all human beings have with this earth. God has made Adam from the dust of the earth (Gn 2:7) and has set him and his race in control over the earth (Gn 1:26; Ps 8:6-8). Adam's fall into sin has had catastrophic consequences for creation itself, and consequently, for human beings as well (Gn 3:17-19; Rm 8:19-22; cf. Hendriksen 1980:267-268).

Humans are related not only to the earth, but also to each other. Social relations were not broken after the Fall, but became twisted (Gn 3:12-16; cf. Van Groningen 1996:103).
The social results of the Fall manifest as early as in Genesis 4. The first victim of murder is not an unbeliever, but a believer: Abel. This is an important fact, as Strydom (2013:65-66) assures us that neither illness nor any physical trauma can touch a believer if he or she only stays under God's 'umbrella of protection' through obedience. Yet, nowhere do we read that Abel had disobeyed God. In fact, God himself testifies of Abel's righteousness (Gn 4:10; Heb 11:4).

The Bible speaks very candidly about the results of the Fall. We read in the Bible of homicide, the murder of children, skin diseases, rape, et cetera - often without any indication that the victims have brought these things over themselves (e.g. Ex 1; Lv 13; Jdg 19:25-27; 2 Sm 13; Jr 22:17; Mt 2:13-18). Dr Strydom is therefore quite right when she says that diseases (and other causes of death) are the results of sin. But here is the important distinction: diseases and other causes of death are not always the result of individual sin, but often they are part of living in the world after humanity's fall into sin (cf. Mbugua 2015a).

An important last remark: It is God himself who ordained that the world should still be subject to the curse of the Fall. Satan did not create the earth, has never owned it, and could not curse it. God himself has cursed his creation. He himself has, to a certain extent, removed his blessed, life-giving presence from creation (Gn 3:17-19; Rm 8:20-21; cf. Morris 1988:321). ${ }^{2}$ Even after Jesus' coming, this is still the case. Only with Jesus' second coming will tears, death and misery be taken away and all things made new ( $R v$ 21:4-5). Christians should be eagerly expecting the complete restoration, the time of which is known only to God (Mbugua 2015a; Morris 1988:325).

\section{A leap from Israel to the New Testament Church}

The above should not be taken to mean that, for the present, God is far from his creation and does not intervene to help his children. However, God's promises of help in the Bible are often interpreted by Strydom in ways that disregard their revelation-historical context.

Strydom's teaching leans heavily on Exodus 15:26 3 and Deuteronomy 28. In Exodus 15:26, God promises to protect Israel against all the diseases that he hit Egypt with if they will obey him. In Deuteronomy 28 he gives a second series of promises. Here he undertakes to give Israel blessings if they will listen to his voice, blessings such as fertility, good crops, a growing livestock, victory in war, honour from the nations, and wealth. If they disobey him, however, they will be cursed in all these areas of life and they will be struck by diseases and plagues. According to Strydom (2013:28-35), it is clear

2.According to Strydom (cf. 2013:132-134) disease, disaster and 'premature' death does not come from God, but from Satan. This idea is clearly contradicted in passages such as 1 Samuel 2:6; Lamentations 2:17; Amos 3:6 and John 19:11.

3.Exodus15:26: 'If thou wilt diligently hearken to the voice of the Lord thy God, and wilt do that which is right in his sight, and wilt give ear to his commandments, and keep all his statutes, I will put none of these diseases upon thee, which I have brought upon the Egyptians: for I am the Lord that healeth thee.' 
that diseases and plagues equal curse because of sin, and health equals blessing because of obedience.

Yet, when reading these passages in their revelation-historical context, it becomes clear that the promises they contain are exceptional promises. They are set against the backdrop of Israel's desert journey after the exodus - a time when rebellious complaints against God became 'a dominant motive' (Currid 2000:327). In Exodus 15, we are told how the people of Israel came to Mara, found only bitter water and began complaining to Moses. Here the Lord gives them the promise that he will not only give them water, but will also protect them against Egypt's diseases, because: 'I am the Lord who heals you' (Ex 15:26). ${ }^{4}$ It is clear that the aim of this promise (and its fulfillment) is that Israel will know the Lord. They should see that he is more powerful than the gods and the magicians of Egypt and that he is their God.

Shortly after the events at Mara, the people start complaining against Moses and Aaron, wishing that they had rather stayed with the 'flesh pots' of Egypt. This time God promises them bread from heaven to eat (Ex 16:1-5). The reason given for this miracle is once again that they will be able to believe in God: 'then you will know that the Lord has led you out of Egypt' (Ex 16:6). (Interestingly, Strydom does not seem to include the promise of manna raining down from heaven among the promises that are valid for believers today.)

The promises of Deuteronomy 28 also are not isolated from Israel's history. In the book of Deuteronomy, Moses is teaching the second generation of Israelites their national history. Before they enter the promised land of Canaan, they should know the events that took place in the preceding 40 years. Moses relates a history full of disobedience notwithstanding God's miraculous salvation (Dt 1-3). Then he repeats the law that God has given him (Dt 3-26). Finally, the blessings and curses are pronounced. Moses firstly commands the elders of the nation to erect great stones after they have crossed the Jordan River. On these stones, the complete law of God should be written (Dt 27:2-3). Then six of the tribes should stand on one mountain and the other six on a mountain opposite. The one mountain represents blessings and the other mountain represents curses (Dt 27:12-13). While they stand there, the Levites should read the curses for disobedience and the whole nation should say 'Amen' to it.

Against the backdrop of Deutenomy 27, it can be realised that the blessings and curses of Deuternomy 28 are connected to the land that Israel is about to enter. They have a national rather than an individual orientation (cf. Kaiser 1988). The stones that should be erected on the border of their new country, as well as the two mountains acting as witnesses of the blessings and curses, indicate that the land of Canaan has been chosen by the Lord as a place where he would reign as King over his people. It is a theocracy (a God-government, that will be based on all the laws found in Deuteronomy 4-26. In this way, the people can live in the land that the Lord promised to Abraham, Isaac and Jacob (Dt 30:20). And they will be a 'kingdom of priests' (Ex 19:6) through which the Lord will show to all the nations of the earth who he is (cf. Wright 2003:280-281).

However, Israel was also taught to expect the visible coming of God's kingdom over not only their land, but the whole earth (Ps 96; Is 2:1-5; 65:17). God's dealings with Israel in the land of Canaan can be described as only one 'act' in the whole 'drama of Scripture' (Bartholomew \& Goheen 2014). This act has already been followed by two other decisive acts: the coming of Jesus Christ, the King promised to Israel, and the present 'in-between time' during which Jesus Christ is building his church (Bartholomew \& Goheen 2014:185).

It seems, to use Bartholomew and Goheen's terms, that Strydom is confusing the acts of the drama. ${ }^{5}$ The New Testament Church is essentially one with the Old Testament Church. Yet, 'several important changes resulted from the accomplished work of Jesus Christ' (Berkhof 1949:571). For one, the present church is not situated in the land of Israel, where the blessings and curses of Deuteronomy had their effect. Moreover, as the book of Hebrews makes clear, the New Testament Church possesses a much fuller revelation of God's kingdom than believers under the Mosaic covenant had enjoyed (Heb 1:1-3; 2:1-4; 3:1-6; 7:11-10:18).

\section{A leap from spiritual to temporary blessings}

Strydom interprets various passages of Scripture through the lense of the prosperity gospel and concludes confidently that 'God's perfect will is not healing - his perfect will is that you don't get sick' (Strydom 2013:62). One of these passages, which is also of personal significance to Strydom (2013:65-68) and her family, is Psalm 91. She rightly encourages Christians to take the promises in this Psalm seriously. These include promises such as the following: 'A thousand shall fall at thy side, and ten thousand at thy right hand; but it shall not come nigh thee', and 'There shall no evil befall thee, neither shall any plague come nigh thy dwelling.'

Yet, Strydom fails to oversee the whole book of Psalms and thus overlooking the tension that is found throughout the Psalms (Helberg 2011:200). The Psalms assure us: 'A thousand shall fall at thy side, and ten thousand at thy right hand; but it shall not come nigh thee.' But there is also doubt and wrestling with God: 'Lord, why castest thou off my soul? Why hidest thou thy face from me?' (Ps 88:15). The Psalms proclaim with confidence: 'For, lo, thine enemies, O Lord, for, lo, thine enemies shall perish; all the workers of iniquity shall be scattered' (Ps 92:9). Yet, there is also anguish: 'Lord, how long shall the wicked, how long shall the wicked triumph?' (Ps 94:3).

5.Not surprisingly, Strydom (2013:215-224) sees the Old Testament customs regarding rest, sleep and food (things which are called a 'shadow' of Christ in Col $2: 16-17)$ as still binding for Christians today. 
Seen within the context of the rest of the Psalms and of all of Scripture, the Psalms of confidence (such as Ps 16, 23 and 91) seem to teach us at least two things: On the one hand, we should rest secure in God's faithfulness and power, praying and thanking him for his protection in all kinds of calamities. On the other hand, when he does allow calamity in our lives, we should trust his good providence and remember that he will work all things for our good ( $\mathrm{Rm} \mathrm{8:28;} \mathrm{cf.}$ Robertson 1995:244).

Paul, when praising God for his spiritual blessings, mentions firstly the blessing of God having 'chosen' us 'to be holy and without blame before him' (Eph 1:3-4). The same idea is found in Romans 8 . When believers hear that all things will work together for their 'good' ( $\operatorname{Rm} 8: 28)$, they are immediately led to Paul's definition of 'good', that is, to be conformed to the image of Jesus Christ (Rm 8:29). Thus, the quadruplegic author and leader of disability ministries, Joni Eareckson Tada (2016), concludes:

God permits what he hates in order to accomplish that which he loves ... God hates spinal chord injury, he hates mental illness, autism and all the rest, yet, he permits these things in order to accomplish something far more precious in our lives, and that is: patience, endurance, compassion, refined faith, and best of all, a deeper trust in God and a love for the Saviour.

Strydom (2013:42) also emphasises the importance of 'sanctification', that is, of 'getting rid of $\sin ^{\prime}$. Yet, her view of $\sin$ is distorted, resulting in a distorted view of God's mercy and his blessing. To her, 'sin is a being [the devil, or an evil spirit] and not a state of being' (Strydom 2013:90; compare to this the Heidelberg Catechism Question and Answer 5). If sin is not inherently part of human nature, it follows that 'your mind [and the behaviour flowing from it] is totally in your control' (Strydom 2019). God's mercy is simply the 'measure of time that is given for you to figure out what He said and apply it to your life' (Strydom 2013:40).

This superficial understanding of the human problem of sin and of God's mercy, gives rise to a view of God's blessing as self-earned, guaranteed, and overly focused on bodily and psychological well-being. John $3: 2^{6}$ is reformulated to say: 'To the extent your mind prospers so your body prospers' (Strydom 2019).

In joining disease directly to sin's curse, Strydom (2013:30) disregards the completed work of Christ, whereby he has removed from us God's curse for $\sin$ (Heb 10:10-14; Gl 3:14; cf. Kaiser 1988). Strydom also denies the biblical injunction given to believers to share in Christ's suffering (Rm 8:14; Phlp 3:10, 15; Col 1:24) and to fix their hope on the future resurrection (1 Cor 15:19; $1 \mathrm{Pt}$ 1:3-7). Strydom's theology has no place for the group of believers, honoured in Hebrews 11:35-47, who 'were tortured ... sawn asunder ... slain with the sword ...' and were willing to suffer anything for the sake of future glory.

6.'Beloved, I wish above all things that though mayest prosper and be in health, even as thy soul prospereth.'

\section{Leaps from one verse to the next}

Strydom repeatedly interprets Bible passages out of their context, or simply incorrectly. I want to highlight three instances, because they have important implications for our understanding of disease and health:

\section{Job}

The book of Job confronts Strydom with a challenge. Here is the story of a man who suffered and became ill, and this while he was 'perfect and upright, and one that feared God, and eschewed evil' (Job 1:1). Strydom finds her solution in Job 1:5, where it is said that Job was concerned about his children and their lifestyle, and in Job 3:25, where it is said that Job 'feared'. Strydom (2013:36-37) concludes that Job feard and that fear opened the door for all his losses losses. Of course this conclusion is directly at odds with the message of the book of Job. At the beginning of the book, the Lord himself confirms Job's innocence (Job 1:8). After Satan has tested Job with the loss of all his children, servants and livestock, we are still told that Job did not react in sin (Job 1:22). Eventually, Job's friends approach him with the same accusation as that is made by Strydom: that there must have been $\sin$ in his life so that these disasters have occurred. It is significant that Job eventually interceded and asked God to forgive his friends for their foolish words (Job 42:7-8).

The reader of Job is left with a message that - I think Strydom is not willing to accept: We cannot understand the ways of God. He does not need to give us an answer as to why we sometimes suffer and hurt. Yet, we can fully trust in him, as he is perfectly wise and righteous (Job 38:1-42:6). In negating the message of Job, Strydom robs her followers of a God-given resource that gives real hope and comfort in times of adversity (cf. Guthrie 2015).

\section{Philippians 2:25-30}

In the New Testament, we meet another righteous sufferer, a man with the name Epaphroditus. He is a coworker of Paul who became deadly ill during a period of ministry (Phlp 2:25-30). According to Strydom, he must have fallen ill, because he worked too hard and did not trust God enough. However, nowhere in this passage do we find any indication that Epaphroditus was admonished or had to repent of an addiction to work. In his mercy, God healed Epaphroditus, after which Paul sent him on his next (exhausting) journey! Moreover, Paul told the Philippians to hold Epaphroditus 'in reputation', because he was willing to risk his life 'for the work of Christ'.

\section{Thessalonians 5:23}

In 1 Thessalonians 5:23, Paul expresses his wish for the Thessalonians: 'I pray God your whole spirit and soul and body be preserved blameless unto the coming of our Lord Jesus Christ.' Strydom interprets this as an indication that God wants our bodies to be healthy and whole until the end. Yet, the word 'blameless' does not mean 'without disease or suffering'. 
It means 'without sin' or 'pure' (Grundmann 1967). The same Greek word (amemptos) is also used in 1 Thessalonians 2:10 to refer to Paul and his co-workers who behaved 'unblameably'.

Strydom's interpretations are not all her own. Most of her 'revolutionary' teachings (Strydom 2013:35) come from one individual, namely the American pastor, Henry Wright. Like Wright, she prefers the King James Version (KJV) translation of the Bible. The New International Version (the most common used English translation of today), is said to have made '38 000 doctrinal changes' to the original Word of God (Strydom 2013:102). ${ }^{7}$

Henry Wright arguably prefers the KJV, because many of his teachings depend on the exact English words that the KJV uses. ${ }^{8}$ A clear example of this in Strydom's own work (2013) is on page 103, where she bases her understanding of 2 Corinthians 5:17 on an incorrect understanding of the archaic English phrases 'are past' and 'are become'. These phrases are used in the KJV to translate Greek past tense verbs in the aorist and perfect tenses respectively. ${ }^{9}$ Yet, Strydom understands the KJV phrases to refer to the present tense - and on this understanding she bases a whole series of teachings.

\section{Conclusion}

When considering the leaps that Strydom makes in her attempt to interpret the Bible in medical terms, it must be concluded that she has taken the most dangerous leap of all: the leap from the gospel to a substitute message. The problem of sin and God's mercy in Christ are watered down to become merely a matter of human decisions and their consequences. The focus shifts from the hope of the resurrection to the guarantee of a long and healthy life, earned through obedience, on this earth. Like all versions of the prosperity gospel, Strydom's specific version empties the gospel of its power (cf. Mbugua 2015b).

I trust that Dr Strydom's book contains medical insights that are worthwhile to ponder. However, I conclude with three reservations concerning her scientific reasoning:

- The overwhelming majority of her medical statements come from one author only, namely Dr Caroline Leaf. ${ }^{10}$

- Her theories are difficult to falsify. Who of us do not sometimes experience anxiety, doubt, fear and family problems? If someone suffering from allergies learns that allergies come from deeply embedded fears (Strydom 2013:336-337), this person will probably easily be able to 'confirm' this connection in his or her own life.

- One should ask why it is the case that the poor in mostly southern parts of the world generally has a lower life expectancy and are plagued by more diseases than those in

7.It goes without saying that Strydom is mistaken here. For a compact explanation of the differences between the various English translations of the Bible, see Wallace (2004).

8. Henry Wright's theology is criticised on several evangelical and Reformed platforms (e.g. Keathley 2000). Much of his critique can also be applied to Strydom's work.

9.This is the reason why, in the New King James Version, these phrases have been translated as 'have passed away' and 'have become new'.

10.Dr Leaf is a neuropsychologist whose work on 'the mind-brain connection' has made her a popular author and speaker, especially in South Africa and the USA. the northern parts of the world. Or why the average life expectancy is so much higher today than was the case in previous centuries. Is it because the northern peoples, and the peoples of the 21st century are following biblical principles to a larger extent? Or is it because people in southern countries have more sin in their family histories (cf. Strydom 2013:151-158)? This is hard to believe.

\section{Acknowledgements Competing interests}

The author has declared that no competing interests exist.

\section{Author's contributions}

I declare that I am the sole author of this research article.

\section{Ethical consideration}

Ethical clearance was not needed or required for the study.

\section{Funding information}

This research received no specific grant from any funding agency in the public, commercial, or not-for-profit sectors.

\section{Data availability statement}

Data sharing is not applicable to this article as no new data were created or analysed in this study.

\section{Disclaimer}

The views and opinions expressed in this article are those of the author and do not necessarily reflect the official policy or position of any affiliated agency of the author.

\section{References}

Bartholomew, C.G. \& Goheen, M.W., 2014, The drama of Scripture: Finding our place in the biblical story, 2nd edn., Baker Academic, Grand Rapids, MI.

Berkhof, L., 1949, Systematic theology, Banner of Truth, Edinburgh.

Coetzer, W., 2013, Trauma: Die meedoënlose vyand, V\&R Drukkery, Pretoria.

Currid, J.D., 2000, A study commentary on Exodus: Chapters 1 to 18, Evangelical Press, Durham.

Eagles' Wings, n.d. 1, The Ministry, viewed 09 May 2019, from http://www. eagleswings.co.zw/about/about.html.

Eagles' Wings, n.d. 2, Resources by Dr MK Strydom, viewed 09 May 2019, from http:// www.eagleswings.co.zw/about/about.html.

Grundmann, W., 1967, ' $\alpha \mu \varepsilon \mu \pi \tau \tau^{\zeta}$ ', in G. Kittel (ed.), Theological dictionary of the Old Testament, vol. 4, p. 572, Eerdmans, Grand Rapids, MI.

Guthrie, N., 2015, Holding on to hope: A pathway through suffering to the heart of God, Tyndale Momentum, Carol Stream, IL.

Helberg, J.L., 2011, Die Here regeer, V\&R Drukkery, Pretoria.

Hendriksen, W., 1980, Exposition of Paul's epistle to the romans, Baker Academic, Grand Rapids, MI. (New Testament Commentary).

Kaiser, W.C. Jr., 1988, 'The Old Testament promise of material blessings and the contemporary believer', Trinity Journal 9(2), 151-170.

Keathley, H. IV, 2000, A review of: A more excellent way by Henry Wright, Bible.org, Richardson, TX, viewed 10 May 2019, from https://bible.org/article/review-moreexcellent-way-henry-wright.

Magezi, V. \& Manzanga, P., 2016, 'Prosperity and health ministry as a coping mechanism in the poverty and suffering context of Zimbabwe: A pastoral evaluation and response', In die Skriflig 50(1), a2076. https://doi.org/10.4102/ids.v50i1.2076

Maura, M.O., Mbewe, C., Mbugua, K., Piper, J. \& Grudem, W., 2015, Prosperity? Seeking the true gospel, Africa Christian Textbooks, Nairobi. 
Mbugua, K., 2015a, 'Suffering', in Prosperity? Seeking the true gospel, pp. 65-78, Africa Christian Textbooks, Nairobi.

Mbugua, K., 2015b, 'Introduction: A false gospel', in Prosperity? Seeking the true gospel, pp. 1-13, Africa Christian Textbooks, Nairobi.

Morris, L., 1988, The epistle to the Romans, Eerdmans, Grand Rapids, MI. (The Pilla New Testament Commentary).

Robertson, O.P., 1995, Psalms in congregational celebration, Evangelical Press, Durham.

Strydom, M.K., 2013, Healing begins with sanctification of the heart, 4th edn., Eagles Wings' Ministries, Harare, viewed 22 November 2019, from https://www. eagleswings.co.zW/Free $\% 20$ Books/Sanctification $\% 20$ of $\% 20$ the $\% 20$ Heart $\% 20$ 4th\%20Edition.pdf.
Strydom, M.K., 2019, 'The Bible from a medical perspective; Medicine from Biblical perspective', Eagles Wings Conference, Bet Shalom Church, Polokwane, April 12-15.

Tada, J.E., 2016, Why does God allow suffering?, video recording, Joni \& Friends, viewed 10 May 2019, from https://www.joniandfriends.org/why-does-god-allow-suffering/.

Van Groningen, G., 1996, From creation to consummation, vol. 1, Dordt College Press, Sioux Center, IA.

Wallace, D.B., 2004, Why so many versions?, Bible.org, viewed 10 May 2019, from https://bible.org/article/why-so-many-versions.

Wright, C.J.H., 2003, Deuteronomy, Hendrickson Publishers, Peabody, MA. (New International Biblical Commentary: Old Testament Series). 